\title{
Degradation and mineralization of coral mucus in reef environments
}

\author{
Christian Wild ${ }^{1, *}$, Mohammed Rasheed ${ }^{2}$, Ursula Werner $^{1}$, Ulrich Franke ${ }^{1}$, \\ Ron Johnstone ${ }^{3}$, Markus Huettel ${ }^{1,4}$
}

\begin{abstract}
${ }^{1}$ Max Planck Institute for Marine Microbiology, Celsiusstrasse 1, 28359 Bremen, Germany
${ }^{2}$ Marine Science Station, University of Jordan and Yarmouk University, PO Box 195, Aqaba, Jordan

${ }^{3}$ Centre for Marine Studies, The University of Queensland, Brisbane, Queensland 4072, Australia

${ }^{4}$ Department of Oceanography, Florida State University, Tallahassee, Florida 32306-4320, USA
\end{abstract}

\begin{abstract}
With in situ and laboratory chamber incubations we demonstrate that coral mucus, an important component of particulate organic matter in reef ecosystems, is a valuable substrate for microbial communities in the water column and sandy sediments of coral reefs. The addition of coral mucus to the water of benthic chambers placed on lagoon sands in the coral cay Heron Island, Australia, resulted in a rapid and significant increase in both $\mathrm{O}_{2}$ consumption and DIC production in the chambers. The permeable coral sands permitted the transport of mucus into the sediment with interfacial water flows, resulting in the mucus being mainly ( $>90 \%$ ) degraded in the sediment and not in the water column of the chambers. A low ratio of 0.48 (in situ) to 0.64 (laboratory) for $\mathrm{O}_{2}$ consumption/DIC production after the addition of coral mucus, and high sulfate reduction rates (SRR) in natural sediments which were exposed to coral mucus, suggest a large contribution of anaerobic processes to the degradation of coral mucus. Oxygen penetrated less than $5 \mathrm{~mm}$ deep into these sediments. The microbial reaction to mucus addition was rapid, with a calculated in situ C turnover rate ranging from 7 to $18 \% \mathrm{~h}^{-1}$. The degradation of coral mucus showed a dependency on the permeability of the carbonate sediments, with faster degradation and remineralization in coarse sands. This indicates the importance of permeable reef sediments for the trapping and degradation of organic matter. We suggest that coral mucus may have a function as a carrier of energy to the benthic microbial consumers.
\end{abstract}

KEY WORDS: Coral mucus $\cdot \mathrm{POM} \cdot$ Degradation $\cdot$ Permeable carbonate sands $\cdot \mathrm{O}_{2}$ consumption $\cdot$ DIC production $\cdot \mathrm{C}$ turnover

Resale or republication not permitted without written consent of the publisher

\section{INTRODUCTION}

Despite the high abundance of coral mucus in the suspended matter of reef waters, its role in the cycling of matter in coral reef environments is unknown. In this study, we present the first experimental results addressing benthic microbial degradation of coral mucus. For these experiments we used stirred benthic chambers that were deployed both in the laboratory and in situ at Heron Island, Australia.

Hard and soft corals continuously produce mucus in ectodermal cells and release it as a transparent, moderately viscous, runny liquid (Ducklow \& Mitchell 1979b). Coral mucus secretion is a protection mecha- nism against sedimentation (Hubbard \& Pocock 1972, Schuhmacher 1977) or increased particle load in the water (Rublee et al. 1980). It also prevents epiphytic/ epizoic or bacterial growth on the coral surface and, thus, acts against fouling (Ducklow \& Mitchell 1979a). In addition, mucus is used to capture prey (Lewis \& Price 1976, Lewis 1978, Goldberg 2002). Those corals growing very close to the water's surface protect themselves against desiccation during aerial exposure at low tide by mucus secretion (Krupp 1984).

The secreted mucus is transported on the coral surface by ciliary currents, and is subjected to a range of physical and chemical processes that can cause the separation of mucus from the coral surface, leading to 
the formation of mucus webs, flocs, threads (Coles \& Strathman 1973) or complex organic aggregates (Marshall 1968). These mucus structures are almost neutrally buoyant and, thus, persist in the water column and can dominate the suspended particulate matter in reef waters (Johannes 1967, Marshall 1968).

Coral mucus is primarily a carbohydrate complex (Coffroth 1990), but also contains energy-rich lipid compounds like wax esters (cetyl palmitate), triglycerids, free fatty acids (Benson \& Muscatine 1974, Crossland et al. 1980) and proteins or peptides (Krupp 1985, Vacelet \& Thomassin 1991). More detailed information about the chemical composition of coral mucus was presented by Richards et al. (1983), who found proteoglycan consisting of D-arabinose, N-acetyl-2amino-2-deoxy-D-glucose and D-mannose as main component of the mucus released by the staghorn coral Acropora formosa. Mucus released from corals has a relatively high nitrogen content (Coles \& Strathman 1973), while most other detritus in reef environments is nitrogen-poor (Hickel 1974).

Coral mucus represents a food source for reef zooplankton (Richman et al. 1975, Gottfried 1983, Marsden \& Meeuwig 1990), crabs (Rinkevich et al. 1991, Stachowicz \& Hay 1999), shrimps (Daumas et al. 1982, Patton 1994), bivalves (Shafir \& Loya 1983), fish (Johannes 1967, Benson \& Muscatine 1974), Gorgonian soft corals (Coffroth 1984), and even brittle stars (Grange 1991).

Mucus layers on corals and mucus aggregates suspended in the water column are colonised by communities of marine heterotrophic bacteria (Ducklow \& Mitchell 1979a). These bacteria may convert mucus compounds into bacterial organic matter, enhancing the nutritional quality (Coles \& Strathman 1973), thus making coral mucus more valuable for reef detritus feeders (Ducklow \& Mitchell 1979a). Although coral reefs are generally associated with oligotrophic waters, high primary production rates $\left(1500\right.$ to $5000 \mathrm{gC} \mathrm{m}^{-2}$ $\mathrm{yr}^{-1}$ ) are reported for these ecosystems (Odum \& Odum 1955, Lewis 1977, Kinsey 1983). Many authors explain these findings with a short linked nutrient cycle between autotrophs and heterotrophs. The symbiosis between corals and zooxanthellate dinoflagellates is a well-known example of this nutrient-preserving mechanism. Because of the large number of algal endosymbionts, and the close metabolic dependence on them, hermatypic corals can be seen as functional autotrophic animals (Schlichter et al. 1983). Production, release and consumption of mucus is mentioned as one mechanism for the transfer of energy from corals and their zooxanthellae to other reef organisms (Coles \& Strathman 1973, Benson \& Muscatine 1974, Ducklow \& Mitchell 1979a). Crossland et al. (1980) found that mucus released by the coral Acropora acumineata corresponded to approximately $40 \%$ of the net carbon fixation by the zooxanthellae. Davies (1984) suggested that a loss of $49 \%$ of the fixed energy could be attributed to mucus secretion of Pocillopora eydouxi. Similar values were also reported by Herndl \& Velimirov (1986), who calculated a $44 \%$ respiratory loss due to mucus release in the Mediterranean hermatypic coral Cladocora cespitosa, and Johannes (1967), who estimated a mucus release of ca. $40 \%$ of coral respiration. Ikeda \& Miyachi (1995) even calculated that $98 \%$ of the net carbon assimilated by zooxanthellate photosynthesis is released from Fungia sp. as exudates, including coral mucus.

Our own observations in the lagoons of Heron and Lizard Island (Great Barrier Reef, Australia) indicated that coral mucus aggregates are an important component of POM (particulate organic matter) in the water column, especially after low tide. We also observed that suspended mucus aggregates gain density due to the attachment of microflora/fauna, resuspended sediment, and eventually sink to the benthos and carbonate sediments.

Benthic sediments in reef ecosystems, consisting mainly of carbonates originating from skeletal material of corals and other benthic organisms, are characterised by a high permeability, porosity and specific surface area, and permit water flow through the sediment. Due to their high specific surface area, large numbers of bacteria are able to settle and grow on the carbonate grains. These factors illustrate the biocatalytic potential of permeable reef sands for the filtration and degradation of organic matter. The current knowledge outlined above suggests that coral mucus may play an important role in the cycling of matter in coral reef ecosystems.

In this study we present the first experimental results on the degradation and mineralization of coral mucus in the benthic environments of a reef lagoon. In a set of laboratory and in situ chamber experiments, we added mucus to the chamber water and then measured dissolved $\mathrm{O}_{2}$ as the electron acceptor for aerobic respiration, and dissolved inorganic carbon (DIC) as end product of reduced organic matter mineralization. In order to assess the potential role of carbonate sands for the uptake and degradation of mucus, we also tested the dependence of $\mathrm{O}_{2}$ consumption and DIC production on sediment permeability. Finally, we also measured sulfate reduction rates (SRR), dissolved $\mathrm{O}_{2}$ distribution and dissolved $\mathrm{O}_{2}$ penetration depths in cores from the chamber experiments to assess the contribution of anaerobic processes to the degradation of coral mucus in reef sediments.

We hypothesised that pore-water flows facilitate the transport of coral mucus into the bed, promoting the importance of the carbonate sands for the degradation of this important component of the coral reef POM pool. 
Table 1. Physico-chemical properties of, and bacteria counts in, the sediments used for different experiments. TOC: total organic carbon

\begin{tabular}{|lcccccc|}
\hline Sediment & $\begin{array}{c}\text { Median grain size } \\
(\mu \mathrm{m})\end{array}$ & $\begin{array}{c}\text { Permeability } \\
\left(10^{-10} \mathrm{~m}^{2}\right)\end{array}$ & $\begin{array}{c}\text { Porosity } \\
(\%)\end{array}$ & $\begin{array}{c}\text { Surface area } \\
\left(\mathrm{m}^{2} \mathrm{~g}^{-1}\right)\end{array}$ & $\begin{array}{c}\text { TOC } \\
(\%)\end{array}$ & $\begin{array}{c}\text { Bacteria count } \\
\left(10^{9} \mathrm{cells}^{-3}\right)\end{array}$ \\
\hline Shark Bay & 829 & 1.22 & 45.5 & 0.29 & 0.24 & 1.71 \\
Coarse sand & 838 & 3.75 & 45.0 & 0.18 & 0.18 & 0.85 \\
Medium sand & 536 & 1.17 & 44.6 & 0.31 & 0.21 & 3.06 \\
\hline
\end{tabular}

\section{MATERIALS AND METHODS}

Study site. The experiments were conducted at Heron Island, Australia (232 $\left.7^{\prime} \mathrm{S}, 151^{\circ} 55^{\prime} \mathrm{E}\right)$ in February 2001 and January 2002. The island is situated on the Tropic of Capricorn, at the southern boundary of the Great Barrier Reef, $70 \mathrm{~km}$ offshore from Gladstone (Fig. 1). Laboratory experiments were carried out in the facilities of the Heron Island Research Station, and field experiments were conducted in Shark Bay, a shallow-water site (at ca. 0.2 to $2.5 \mathrm{~m}$ water depth, depending on tide) at the south-eastern end of the island. The sediments used for laboratory experiments were also collected in Shark Bay, and consisted of carbonate sands of biogenic origin (Table 1). During the in situ experiments, the weather was calm, wave heights did not exceed $30 \mathrm{~cm}$, and bottom currents (measured $10 \mathrm{~cm}$ above the sediment surface) were less than $15 \mathrm{~cm} \mathrm{~s}^{-1}$. Ripple formation, scouring or re-deposition of sediment was not observed in any of the field experiments. The sediment surface was relatively smooth, with topography not exceeding $1 \mathrm{~cm}$ in height.

Sediment analyses. Grain-size distribution was assessed by sieving through a calibrated sieve stack, and sediment permeability was measured in sediment cores using a constant-head permeameter as described by Klute \& Dirksen (1986). Porosity was calculated from weight loss of a known volume of wet sediment after drying at $60^{\circ} \mathrm{C}$ for $24 \mathrm{~h}$. Specific surface areas of

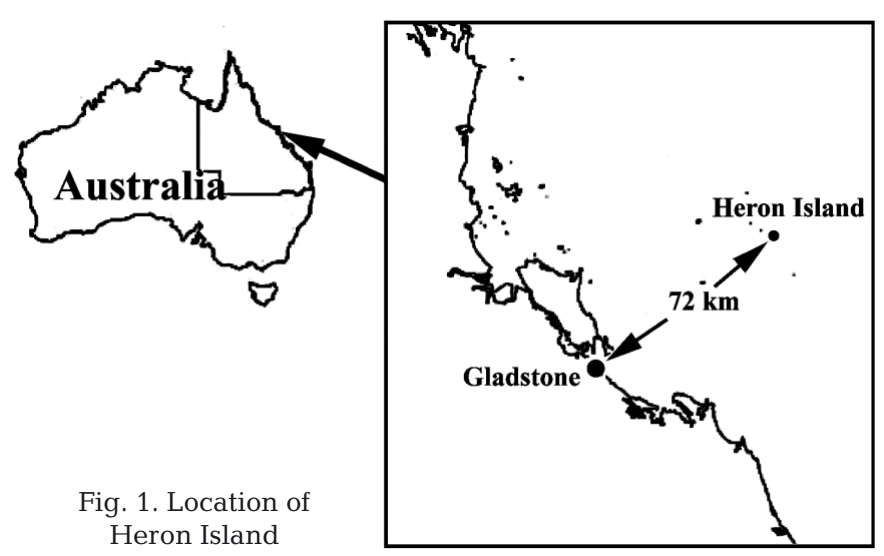

the sediments were determined by measuring nitrogen adsorbed to the dry grain surfaces using a Quantachrome Quantasorb instrument. Total organic carbon (TOC) and total nitrogen (TN) content were measured using a Heraeus CHNO rapid elemental analyzer, with sulfanilamide as a calibration standard. The samples were pre-treated with 6 N HCL until gas development ceased, and then washed twice with distilled water and dried at $60^{\circ} \mathrm{C}$.

Bacterial counts in carbonate sediments. For bacterial counts in carbonate sediments, we used the acridin orange direct count (AODC) method (Hobbie et al. 1977) with some modifications. For each sample, $2 \mathrm{ml}$ of formaldehyde $(2 \%)$ in acetic acid $(2 \%)$ was added to the sediment $\left(1 \mathrm{~cm}^{3}\right.$ preserved with formaldehyde at $3 \%$ final concentration). The samples then were mixed and subsequently subjected to pulsed ultrasonic treatment (30\% for $150 \mathrm{~s}$, Bandelin MD72, vials on ice). The sand grains were allowed to settle for $20 \mathrm{~s}$, and the supernatant was removed. The remaining sediment was washed at least 6 times with the acetic acid solution, and all supernatants were combined. This ultrasonic treatment, with subsequent washing, was repeated 3 more times. Bacteria were counted in subsamples from the combined supernatants. Aggregates were disintegrated by weak ultrasonic treatment (duration: 10 to $30 \mathrm{~s}$ ) when necessary. Bacteria were counted in natural Shark Bay sediments as well as in both sediment fractions used in the laboratory incubations (Table 1).

Mucus collection. In the reef flats around Heron Island, clusters of branching corals of the genus Acropora form scattered patches on the sediment. The lower dead branches anchor the corals in the carbonate sand, and this permits the removal of individual colonies from the sediment without breaking and harming the coral. During low tide, some of these corals are naturally exposed to air. Coral mucus was collected in situ by exposing such intact colonies of several Acropora species from the reef flat $(<2 \mathrm{~m}$ water depth) to air. The colonies rapidly released large amounts of mucus, which was immediately collected by inverting the coral over a pre-cleaned container, which caught the dripping mucus material. After this procedure, the corals were re-anchored in the lagoon 
sediment. The collected mucus was homogenised and stored refrigerated until use. All samplings and mucus addition experiments were carried out within $24 \mathrm{~h}$ of mucus sampling.

Bacterial counts and carbon analysis in coral mucus. Bacteria were counted in triplicate aliquots from the coral mucus that was added to the chambers of the in situ incubation Expt 1. As a control, bacteria were also counted in seawater sampled from the reef flat on the day of mucus collection. All counts were performed using the standard AODC method (Hobbie et al. 1977).

Samples for particulate organic carbon (POC) were prepared by filtering triplicate aliquots of 5 to $10 \mathrm{ml}$ of coral mucus on precombusted GF/F filters (Whatman) using a low vacuum of $150 \mathrm{~mm} \mathrm{Hg}$ pressure. The filters were dried for $24 \mathrm{~h}$ at $40^{\circ} \mathrm{C}$ and wrapped in precombusted aluminium foil. Small carbonate grains in the mucus were removed by exposing the filters to a fuming $\mathrm{HCl}$ atmosphere for $24 \mathrm{~h}$. Carbon values were measured using an elemental analyser (Fisons AT1500) with sulfanilamide (HEKAtech) as standard.

Mucus respiration. In order to measure the $\mathrm{O}_{2}$ consumption of coral mucus in the water column, we incubated freshly collected undiluted Acropora mucus, and as reference (control) local seawater, in $30 \mathrm{ml}$ Winkler bottles under dark conditions and at in situ temperature $\left(26\right.$ to $\left.29^{\circ} \mathrm{C}\right)$. The $\mathrm{O}_{2}$ concentrations in both treatments were measured in parallel time series using the Winkler titration method.

This mucus respiration measurement was performed for 5 different mucus samplings, including material from 3 mucus samples that were also sub-sampled and used for subsequent incubation in benthic chambers. For each bottle incubation experiment, $\mathrm{O}_{2}$ consumption rates were calculated in $\mu \mathrm{M} \mathrm{d}^{-1}$ using linear regression with at least 4 data points.

Chamber incubation experiments. The benthic degradation and mineralization of coral mucus was investigated in 2 laboratory and 4 in situ chamber incubation experiments (Table 2). The in situ incubations were undertaken in Shark Bay, while sieved sediment fractions characterised by different permeabilities were used as the sedimentary medium incubated in the laboratory experiments. The in situ incubations started $2 \mathrm{~h}$ after low tide and ended 2 to $7 \mathrm{~h}$ later. The laboratory incubations ran for $6 \mathrm{~h}$. During all incubations, water samples (30 to $100 \mathrm{ml}$ ) were taken at preset time intervals (30 to $60 \mathrm{~min}$ ) from the chamber water for later analyses of $\mathrm{O}_{2}$ and DIC. In one experiment, additional water samples were taken for the analysis of $\mathrm{Br}^{-}$, a solute tracer added to the chamber water (see below and Table 2). Fluxes of solutes were evaluated by linear regression of solute concentrations over time. After termination of one in situ chamber experiment, sediment cores (1 core per chamber) were collected for the analysis of SRR.

Chamber design: We used cylindrical chambers made of acrylic with a height of $30 \mathrm{~cm}$ and an inner diameter of $19 \mathrm{~cm}$. Plastic lids covered the chambers and were fixed by 4 stainless-steel clips. Each lid contained a sampling port with syringe holder for water samples, and another port to replace the sampled water with seawater. A third opening in the lids contained a fibre-optic oxygen microsensor. A horizontally rotating disk of $15 \mathrm{~cm}$ diameter agitated the water in the chambers. The disks, driven by $12 \mathrm{~V}$ DC motors, rotated at ca. $8 \mathrm{~cm}$ above the sediment at an electronically controlled speed of $20 \mathrm{rpm}$. The ensuing water column rotation generates a pressure gradient at the sediment surface of 1.2 Pa between the centre and the chamber wall. Pressure gradients at this order of magnitude develop when sediment topography and boundary flows found at the study site interact (Huettel \& Gust 1992, Glud et al. 1996a, Huettel \& Rusch 2000).

In situ incubations: The chambers were inserted gently into the sediments to a depth of ca. $8 \mathrm{~cm}$, marked by a ring of tape on the chamber wall, and thus included a water column of approximately $22 \mathrm{~cm}$ height. The chambers were then closed and sealed from light by wrapping with opaque black PVC foil. Recordings of light intensity and temperature at $2 \mathrm{~min}$ intervals underneath the PVC foil and in the surrounding areas, using Onset ${ }^{\mathrm{TM}} \mathrm{HOBO}$ light loggers made

Table 2. Overview of all mucus chamber incubations carried out at Heron Island. DIC: dissolved inorganic carbon; SRR: sulfate reduction rate

\begin{tabular}{|lcccc|}
\hline $\begin{array}{l}\text { Date } \\
(\mathrm{dd} / \mathrm{mm} / \mathrm{yy})\end{array}$ & Expt & Mucus (control) chambers & $\begin{array}{c}\text { Water temperature/ } \\
\left.\text { salinity ( }{ }^{\circ} \mathrm{C} / \mathrm{PSU}\right)\end{array}$ & $\begin{array}{c}\text { Parameters measured in } \\
\text { chamber water (-sediment) }\end{array}$ \\
\hline $04 / 02 / 2001$ & In situ 1 & $3(4)$ & $28.2 / 34.0$ & $\mathrm{O}_{2}, \mathrm{DIC}, \mathrm{NaBr}$ \\
$07 / 02 / 2001$ & Laboratory 1 (coarse) & $3(3)$ & $27.2 / 34.5$ & $\mathrm{O}_{2}, \mathrm{DIC}$ \\
$08 / 02 / 2001$ & Laboratory 2 (fine) & $3(3)$ & $27.4 / 34.0$ & $\mathrm{O}_{2}, \mathrm{DIC}$ \\
$15 / 01 / 2002$ & In situ 2 & $2(2)$ & $26.2 / 34.5$ & $\mathrm{O}_{2},(\mathrm{SRR})$ \\
$21 / 01 / 2002$ & In situ 3 & $2(2)$ & $27.2 / 34.0$ & $\mathrm{O}_{2}$ \\
$25 / 01 / 2002$ & In situ 4 & $2(2)$ & $28.3 / 35.5$ & $\mathrm{O}_{2}$ \\
\hline
\end{tabular}


waterproof by shrink-wrapping them in transparent, non-light-absorbing clingwrap, and Tidbit temperature loggers, revealed that no light intrusion or heating occurred in the chambers. Finally, the chambers were secured with lead weights to prevent any movement due to bottom currents or waves.

For each experiment, 4 or 6 of the described benthic chambers were used (Table 2).

At the start of each experiment, 150 to $280 \mathrm{ml}$ Acropora mucus (characteristics listed in Table 3) was added to half of the deployed chambers via one of the syringe ports. In one experiment, the tracer $\mathrm{NaBr}(1.5$ $\mathrm{mM}$ final concentration) was added to all chambers to assess advective interfacial solute exchange. At the end of each experiment, the volume of water in each chamber was determined after removing the lid of the chambers by measurement of water height with a ruler at 4 different positions (N, E, S, W) close to the chamber wall.

Laboratory chamber incubations: In order to assess the effect of sediment permeability on the degradation of coral mucus, 2 laboratory chamber incubations were conducted using sediments of different grain size. Sediment was collected from Shark Bay (6 February 2001) and separated with a sieve $(500 \mu \mathrm{m})$ into a coarse and medium grain-size fraction (829 and $536 \mu$ median grain size, respectively; see Table 1). The experiments were conducted in a similar manner as the in situ experiments. Six benthic chambers, identical to those described above except that they were sealed at the bottom with lids, were placed in a large container flushed by natural seawater, which kept the temperature of incubation at in situ temperature $\left(26\right.$ to $\left.28^{\circ} \mathrm{C}\right)$. The chambers were filled with $4.5 \mathrm{dm}^{3}$ of either the coarse ( 7 February) or the medium (8 February) sediment fraction. The overlying unfiltered seawater had a volume of $4 \mathrm{l}$. After closing the lids, volumes of $200 \mathrm{ml}$ of Acropora mucus were added to 3 of the chambers of each set. During the $6 \mathrm{~h}$ of incubation, the chambers were kept in the dark. At pre-set time intervals, dis- solved $\mathrm{O}_{2}$ was measured and water samples were withdrawn for DIC analysis.

Measurements and analyses: Dissolved $\mathrm{O}_{2}$ concentrations in the chambers were continuously measured in the stirred chambers throughout the incubations by fibre-optic oxygen microsensors (PreSens; Sensor type A, tip diameter $<50 \mu \mathrm{m}$. For the measuring principle see Klimant et al. 1995) mounted in the lids of the chambers or by the Winkler titration method. The microsensors were connected to a Microx-TX fiberoptic oxygenmeter (PreSens). Sensors were calibrated before and after the experiments using a 2-point calibration in oxygen-free (addition of sodium dithionite) and air-saturated seawater.

DIC concentrations in the water samples were determined using a flow injection system (Hall \& Aller 1992). Calibration standards were prepared freshly from $\mathrm{NaHCO}_{3}$. The detection limit of the method was $0.1 \mathrm{mM}$.

Bromide concentrations were determined by ion chromatography using $\mathrm{NaBr}$ as the standard for calibration.

In order to assess whether anaerobic decomposition contributed to the degradation processes associated with addition of coral mucus, SRR were measured within $12 \mathrm{~h}$ of sediment cores being taken (1 core from each chamber) at the end of in situ Expt 2.

SRR were measured in the sediment cores by adding a radiolabelled solution of ${ }^{35} \mathrm{SO}_{4}{ }^{2-}$ (Amersham; specific activity of added solution: $340 \mathrm{MBq}$ per mol $\mathrm{SO}_{4}{ }^{2-}$ ) to the overlying water of each core. By using a peristaltic pump, the overlying water was transported into the permeable core sediment and equally distributed. The cores were then incubated in the dark for $6 \mathrm{~h}$ at ambient temperatures (Expt 1: $33^{\circ} \mathrm{C}$; Expt 2: $28^{\circ} \mathrm{C}$ ). The sediment was subsequently sliced into $1 \mathrm{~cm}$ thick sections and fixed in $20 \%$ ZnAc. Samples were processed using a cold chromium distillation procedure (Kallmeyer et al. unpubl.), with the slight modification that $\mathrm{HCl}$ was added until all carbonates were dis-

Table 3. Carbon content and bacterial abundance in coral mucus (Acropora spp.) used for the chamber incubations. Values are means \pm SE ( $\mathrm{n}$ in replicates, $\mathrm{nd}=$ no data available). SW: seawater; nd: no data

\begin{tabular}{|lccc|}
\hline Sampling date $(\mathrm{dd} / \mathrm{mm} / \mathrm{yy})$ & Used for: & $\mathrm{C}\left(\mathrm{mg} \mathrm{l}^{-1}\right)$ & ${\text { Bacterial count }\left(10^{5} \text { cells } \mathrm{ml}^{-1}\right)}$ \\
\hline $03 / 02 / 2001$ & In situ 1 & $36.8 \pm 7.2(3)$ & $295 \pm 149(3)$ \\
$03 / 02 / 2001$ & SW control & nd & $3.0 \pm 1.7(3)$ \\
$06 / 02 / 2001$ & Laboratory experiments & $51.6 \pm 7.7(3)$ & $292 \pm 31(3)$ \\
$14 / 01 / 2002$ & In situ 2 & $30.9 \pm 0.4(3)$ & nd \\
$14 / 01 / 2002$ & SW control & $1.8 \pm 0.1(3)$ & nd \\
$20 / 01 / 2002$ & In situ 3 & $12.1(1)$ & nd \\
$22 / 01 / 2002$ & SW control & $0.3 \pm 0.1(3)$ & nd \\
$25 / 01 / 2002$ & In situ 4 & $10.8 \pm 0.8(3)$ & nd \\
$25 / 01 / 2002$ & SW control & $0.43 \pm 0.03(3)$ & nd \\
\hline
\end{tabular}


solved. The activity of ${ }^{35} \mathrm{SO}_{4}{ }^{2-}$ and TRIS (total reduced inorganic sulfur) were determined using a liquid scintillation counter (Packard 2500 TR); the scintillation cocktail used was Lumasafe Plus ${ }^{\circledR}$ (Lumac BV, Holland). Sulfate concentrations were determined by non-suppressed ion-chromatography with conductivity detection. SRR were calculated according to:

$$
\mathrm{SRR}=a_{\mathrm{TRIS}} \times \mathrm{SA}^{-1} \times \alpha \times t^{-1}\left(\mathrm{nmol} \mathrm{cm}^{-3} \mathrm{~d}^{-1}\right)
$$

where SRR are sulfate reduction rates $\left(\mathrm{nmol} \mathrm{cm}^{-3} \mathrm{~d}^{-1}\right)$; $a_{\text {TRIS }}$ is activity (counts per min; CPM) in TRIS $\mathrm{cm}^{-3}$; $\alpha$ is correction factor for the expected isotopic fractionation (1.06); $\mathrm{SA}$ is specific activity of sulfate, $\mathrm{SA}=$ $\mathrm{CPM}_{\text {sulfate }} \cdot \mathrm{nmol}_{\text {sulfate }}{ }^{-1} \cdot \mathrm{l}^{-1}\left(\mathrm{CPM} \mathrm{nmol}^{-1}\right)_{i} t$ is time (d).

Oxygen profiles within the stirred chambers: The 2D oxygen distribution and penetration depths in the stirred chambers were measured using semitransparent planar $\mathrm{O}_{2}$ optodes (Glud et al. 1996b, 1998). The optical measuring principle of $\mathrm{O}_{2}$ planar optodes is based on dynamic quenching of the luminescence light of an indicator dye by oxygen (Kautsky 1939). In this study, the sensing layer of the optode consisted of Platinum (II) meso-tetra pentafluorophenylporphyrin (Pt-PFP) embedded in a Poly-styrol-coacrylacidnitril matrix. Detailed description of the planar $\mathrm{O}_{2}$ optode used, acquisition and processing of the images, design of the modified stirring chambers and treatment of the sampled sediment can be requested form U. Franke (ufranke@mpi.bremen.de).

Sediment cores (length $15 \mathrm{~cm}$ ) from Shark Bay were transferred to chambers similar to those used in the laboratory incubations. The overlaying water in the chambers was stirred with a rotating disc at $40 \mathrm{rpm}$,

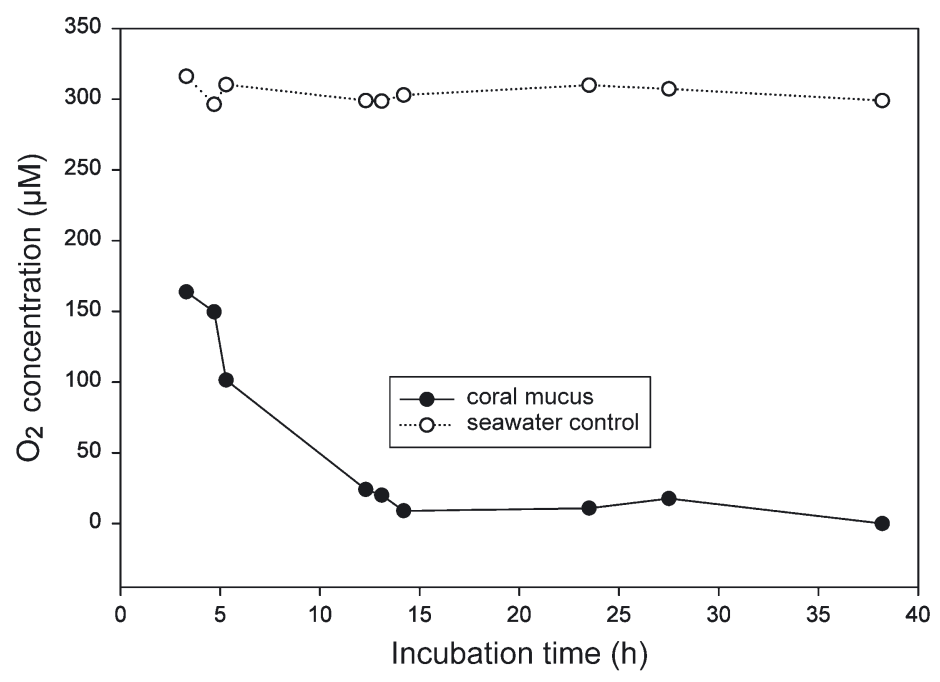

Fig. 2. Oxygen concentrations in bottles filled with natural Acropora mucus or seawater over time. Bottles were incubated at $28^{\circ} \mathrm{C}$ for $38 \mathrm{~h}$
2 -fold the stirring speed used in the incubation experiments, to get information about the maximum $\mathrm{O}_{2}$ penetration into the sediment. Oxygen penetration depths for 3 sediment cores were determined by extracting 5 oxygen profiles out of a smoothed (box-car filter, smoothing value: 8) $2 \mathrm{D} \mathrm{O}_{2}$ image for each sediment sample. This was done when the overlying enclosed chamber water was still saturated with $\mathrm{O}_{2}$. All profiles were extracted at the same relative positions of the $\mathrm{O}_{2}$ images. With the help of black and white digital images taken just before the $\mathrm{O}_{2}$ measurements, the sediment surface was detected and the $\mathrm{O}_{2}$ profiles were normalised to the sediment surface. These digital images covered an area of $24 \times 19 \mathrm{~mm}$ and the spatial resolution was $40 \times 40 \mu \mathrm{m} \mathrm{pixel}{ }^{-1}$.

\section{RESULTS}

\section{Bottle incubations}

In the bottle incubations, coral mucus consumed more $\mathrm{O}_{2}$ than equivalent volumes of seawater, indicating aerobic degradation of the mucus. This result was supported by the bacterial counts, which revealed a ca. 100-fold increase in bacterial numbers in coral mucus compared to the surrounding seawater. Further characteristics of the mucus are listed in Table 3. From the onset of the bottle experiment throughout the entire incubation period, $\mathrm{O}_{2}$ concentrations in the mucus bottles were always significantly lower, and decreased faster, than in the control bottles filled with seawater (Fig. 2). A conservative linear regression analysis (period of 3 to $14 \mathrm{~h}$ ) results in $\mathrm{O}_{2}$ consumption rates of $334 \mu \mathrm{M} \mathrm{d}^{-1}$ for coral mucus and $21 \mu \mathrm{M} \mathrm{d}^{-1}$ for the ambient seawater, corresponding to a $>15$-fold increase in $\mathrm{O}_{2}$ consumption in coral mucus. This result was confirmed by the other 4 mucus incubation experiments, which showed $\mathrm{O}_{2}$ consumption rates to range from 130 to 445 and 5 to $41 \mu \mathrm{M} \mathrm{O}_{2} \mathrm{~d}^{-1}$ for mucus and seawater incubations, respectively.

\section{Chamber incubation experiments}

The coarse Shark Bay sediment was highly permeable (permeability $k$ in the range of $10^{-10} \mathrm{~m}^{2}$ ), and permitted advective pore-water exchange as reflected by our tracer measurements. The average flux of $\mathrm{NaBr}$ into Shark Bay sediments was $54.0 \pm 6.8 \mathrm{mmol} \mathrm{m}^{-2} \mathrm{~d}^{-1}$, which corresponds to a flushing rate of $26 \mathrm{l} \mathrm{m}^{-2} \mathrm{~d}^{-1}$ at the stirring speed of $20 \mathrm{rpm}$.

Despite its large median grain size, the Shark Bay sediment contained $1.71 \pm 0.57 \times 10^{9}$ bacteria $\mathrm{cm}^{-3}$ (Table 1). 


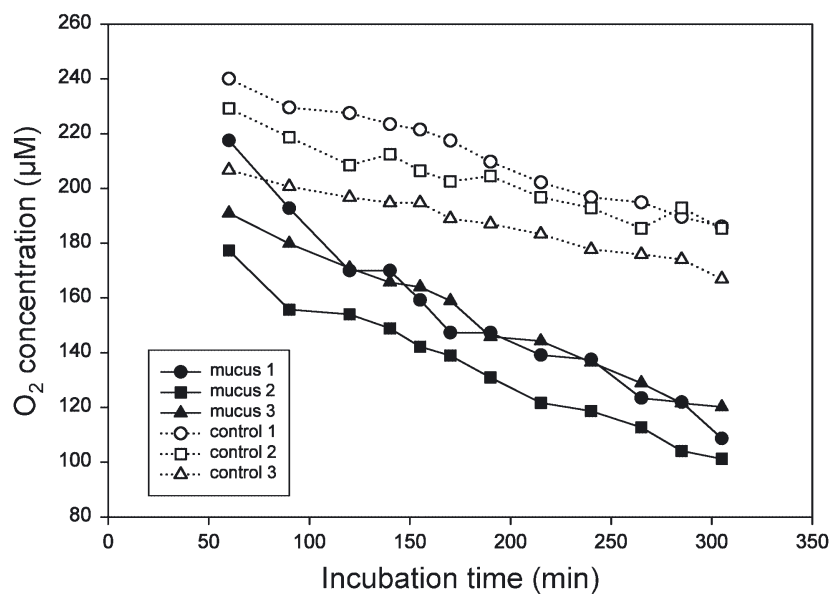

Fig. 3. $\mathrm{O}_{2}$ concentration in 6 benthic chambers during in situ Expt 1. Coral mucus (Acropora spp.) was added to the 3 chambers represented by black symbols. Control chamber values are shown using open symbols

\section{In situ chamber incubations}

In the in situ experiments, the addition of coral mucus (for characteristics see Table 3) caused a 1.2to 1.7 -fold increase in the $\mathrm{O}_{2}$ consumption rate of the amended chambers relative to the control chambers without mucus (Fig. 3). In Expt 2, much higher sulfate reduction rates (up to $1200 \mathrm{nmol} \mathrm{cm} \mathrm{cm}^{-3} \mathrm{~d}^{-1}$ ) were recorded in one of the mucus chambers compared to the control chambers. Integration of sulfate reduction over the first $5 \mathrm{~cm}$ showed sulfate reduction rates of 22.7 to $56.9 \mathrm{mmol} \mathrm{m}^{-2} \mathrm{~d}^{-1}$ in the mucus chambers, compared to between 12.0 and $19.3 \mathrm{mmol} \mathrm{m}^{-2} \mathrm{~d}^{-1}$ in the control chambers. Maximum $\mathrm{O}_{2}$ penetration depths in 14 of 15 profiles (5 measured in each of 3 cores from Shark Bay) were 2.0 to $2.5 \mathrm{~mm}$; only 1 profile showed an $\mathrm{O}_{2}$ penetration $<4.8 \mathrm{~mm}$ into the sediment (Fig. 4). This locally enhanced $\mathrm{O}_{2}$ penetra- tion was caused by bioturbation, as indicated by the shape of the profile.

Higher $\mathrm{O}_{2}$ consumption in the chambers with mucus was accompanied by higher DIC production. In the chambers with mucus, DIC concentrations increased 1.3-fold faster than in the control chambers (Fig. 5).

\section{Laboratory chamber incubations}

Addition of mucus to the laboratory chambers caused a faster $\mathrm{O}_{2}$ decrease relative to the control chambers (Fig. 6) and, thus, supported the results of the bottle and in situ incubations. The effect was more pronounced than in the in situ incubations, and so strong that in the chambers with mucus, anoxia was reached after 200 to $280 \mathrm{~min}$ (coarse sand) and 300 to 360 min (medium sand). This result was unexpected, because the bacterial abundance in the medium sand fraction was 3 times higher than that recorded for the coarse sand fraction (Table 1).

As in the in situ incubation, the DIC increase in the laboratory incubation chambers reflected the higher decomposition activity in the chambers with mucus. Here, the DIC production increased 2.6- (coarse fraction) and 3.2- (fine fraction) fold faster than in the control chambers (Fig. 7).

The amount of organic carbon added as mucus to the chambers ranged from 240 to $870 \mu \mathrm{mol}$ (corresponding to 40 to $220 \mu \mathrm{mol} \mathrm{POC}{ }^{-1}$ ) in all experiments (Table 4 ). In the laboratory experiments, the mucus concentrations in

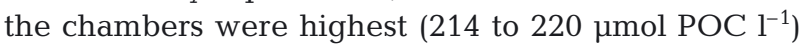
due to the smaller chamber-water volumes. During the in situ experiments, POC concentrations in the chambers were between 40 and $124 \mu_{\mathrm{mol}} \mathrm{l}^{-1}$. Natural POC watercolumn concentrations on the Heron Island reef flat ranged between 14 and $41 \mu \mathrm{mol} \mathrm{l}^{-1}(\mathrm{n}=56)$.

The fluxes of $\mathrm{O}_{2}$ and DIC calculated from all chamber experiments are summarised in Fig. 8. In the 4

Table 4. Degradation of reduced carbon derived from coral mucus (Acropora spp.). Amounts of carbon added to the chambers were calculated from carbon analysis in coral mucus (Table 3). Rates for dissolved inorganic carbon (DIC) production and $\mathrm{O}_{2}$ consumption are calculated from the rates measured in the mucus chambers reduced by the rates measured in the control chambers. Carbon turnover represents the ratio between addition of reduced carbon and the increased release of oxidized carbon as DIC, or the increased consumption of $\mathrm{O}_{2}$ under the assumption that $1 \mathrm{~mol}$ of $\mathrm{O}_{2}$ mineralizes 1 mol of reduced $\mathrm{C}_{i}$ nd: no data

\begin{tabular}{|c|c|c|c|c|c|}
\hline \multirow[t]{2}{*}{ Expt } & \multirow{2}{*}{$\begin{array}{c}\text { C addition } \\
(\mu \mathrm{mol})\end{array}$} & \multicolumn{2}{|c|}{ Release of oxidized carbon } & \multicolumn{2}{|c|}{ Oxygen consumption } \\
\hline & & $\begin{array}{l}\text { DIC produced } \\
\left.(\mu \mathrm{mol} \mathrm{h})^{-1}\right)\end{array}$ & $\begin{array}{c}\text { C turnover } \\
\left(\% \mathrm{~h}^{-1}\right)\end{array}$ & $\begin{array}{c}\mathrm{O}_{2} \text { consumed } \\
\left(\mu \mathrm{mol} \mathrm{h}{ }^{-1}\right)\end{array}$ & $\begin{array}{c}\text { C turnover } \\
\left(\% \mathrm{~h}^{-1}\right)\end{array}$ \\
\hline In situ 1 & 857.9 & 125.3 & 14.6 & 60.3 & 7.0 \\
\hline In situ 2 & 360.2 & nd & nd & 23.2 & 6.5 \\
\hline In situ 3 & 302.2 & nd & nd & 20.1 & 6.7 \\
\hline In situ 4 & 242.8 & nd & nd & 44.2 & 18.2 \\
\hline Laboratory (coarse sand) & 859.2 & 352.0 & 41.0 & 224.9 & 26.2 \\
\hline Laboratory (medium sand) & 872.5 & 208.0 & 23.8 & 113.6 & 13.0 \\
\hline
\end{tabular}



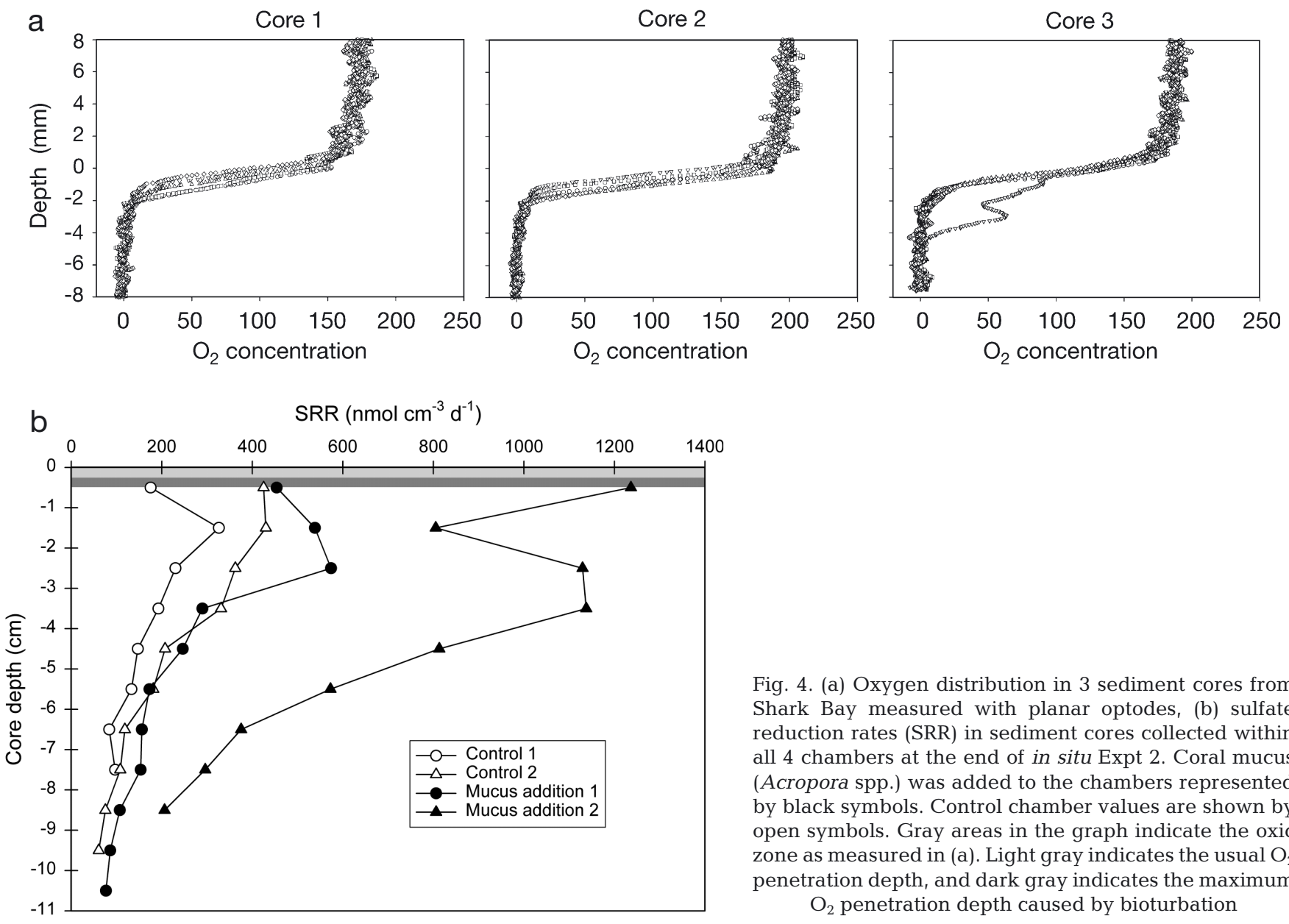

Fig. 4. (a) Oxygen distribution in 3 sediment cores from Shark Bay measured with planar optodes, (b) sulfate reduction rates (SRR) in sediment cores collected within all 4 chambers at the end of in situ Expt 2. Coral mucus (Acropora spp.) was added to the chambers represented by black symbols. Control chamber values are shown by open symbols. Gray areas in the graph indicate the oxic zone as measured in (a). Light gray indicates the usual $\mathrm{O}_{2}$ penetration depth, and dark gray indicates the maximum $\mathrm{O}_{2}$ penetration depth caused by bioturbation

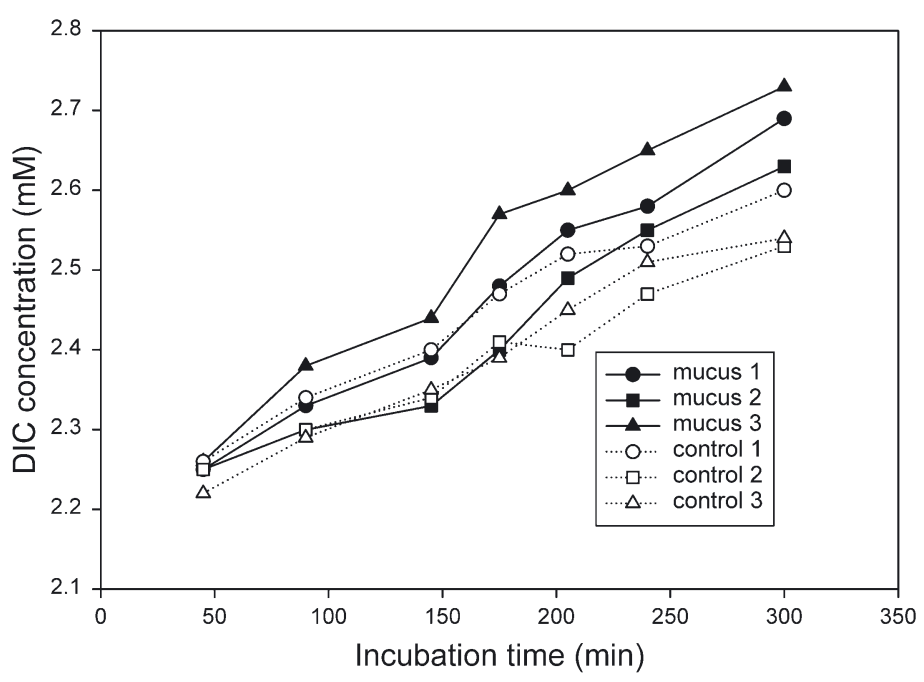

Fig. 5. Dissolved inorganic carbon (DIC) concentration in 6 benthic chambers during in situ Expt 1. Coral mucus (Acropora spp.) was added to the 3 chambers labeled with black symbols. Control chamber values are shown using open symbols in situ experiments, we found in the chambers with mucus addition an increase in $\mathrm{O}_{2}$ consumption of 17 to $46 \mathrm{mmol} \mathrm{m}^{-2} \mathrm{~d}^{-1}$ relative to the controls, while in the 2 laboratory experiments, increases of 109 to $199 \mathrm{mmol}$ $\mathrm{m}^{-2} \mathrm{~d}^{-1}$ were reached. A 2 -sided $U$-test after Wilcoxon, Mann and Whitney showed significant differences ( $\alpha=0.002)$ in sedimentary oxygen consumption between the control and mucus incubation chambers used in situ.

Consumption of $\mathrm{O}_{2}$ was lowest in the controls of laboratory Expt 1 (coarse fraction) and highest in the mucus addition chambers of the same experiment.

Acropora mucus caused an increase in DIC concentration in the overlying water of all 9 experimental chambers where DIC was measured (3 in situ chambers, 6 laboratory chambers). This increase varied between the experiments, with a more pronounced response (higher DIC production) in the addition of coral mucus in the laboratory experiments (176 to $298 \mathrm{mmol}$ $\mathrm{m}^{-2} \mathrm{~d}^{-1}$ compared to $141 \mathrm{mmol} \mathrm{m} \mathrm{m}^{-2} \mathrm{~d}^{-1}$ for the in situ Expt 1). 


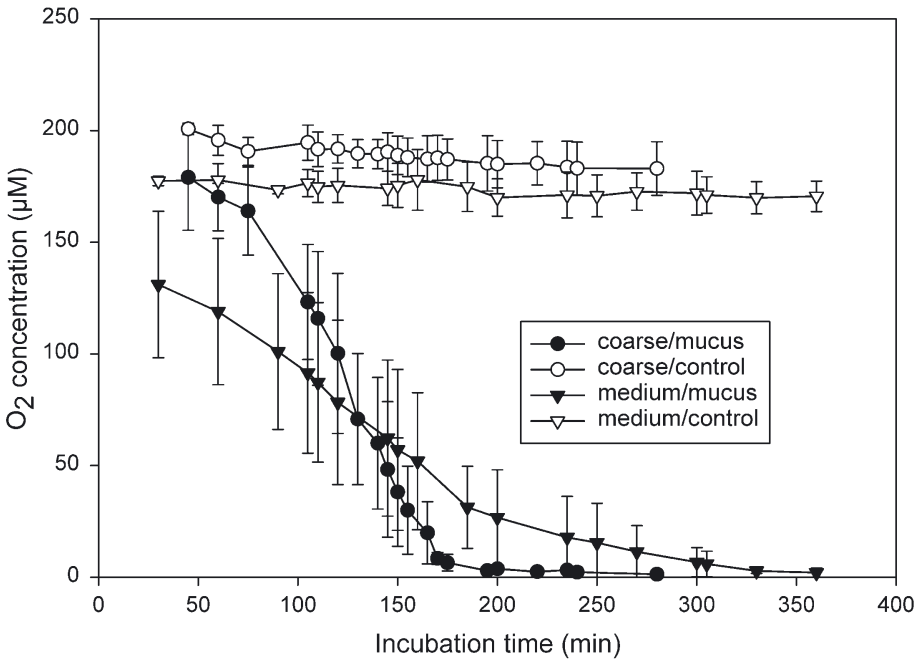

Fig. 6. Mean $\mathrm{O}_{2}$ concentrations in the incubation chambers during both laboratory experiments. Coral mucus (Acropora spp.) was added to the chambers represented by black symbols. Control chamber values are shown by open symbols. Carbonate sediment with either medium (triangles) or coarse grain size (circles) was used. Error bars indicate the SDs of 3 replicate chambers

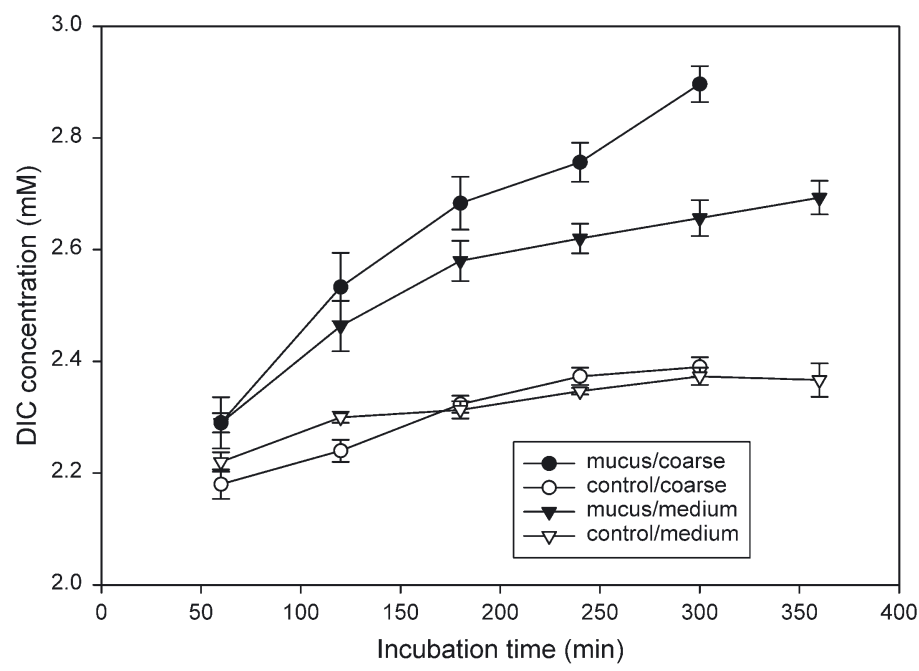

Fig. 7. Mean dissolved inorganic carbon (DIC) concentrations in the incubation chambers during both laboratory experiments. Coral mucus (Acropora spp.) was added to the chambers represented by black symbols. Control chamber values are shown by open symbols. Medium (triangles) or coarse grain size (circles) was used. Error bars indicate the SDs of 3 replicate chambers

The ratio between $\mathrm{O}_{2}$ consumption and DIC production was always below 1 , with the lowest value of 0.48 in the field Expt 1, and values of 0.64 and 0.55 in the laboratory experiments with the coarse and medium sand fraction, respectively.

\section{Carbon degradation and mineralization}

Carbon turnover rates, calculated from both the $\mathrm{O}_{2}$ consumption and DIC production rates, revealed $\mathrm{C}$ turnover rates ranging from 7 to $18 \% \mathrm{~h}^{-1}$ during the in situ experiments, and rates from 13 to 24 and 26 to $41 \% \mathrm{~h}^{-1}$ in the laboratory experiments with the medium and coarse sand, respectively (Table 4). In situ $\mathrm{C}$ turnover rates and rates derived from the experiments with the medium sand fraction were similar, which can be caused by very similar permeabilities of both sediments (see Table 1).

The molar equivalent of increased inorganic $\mathrm{C}$ release to added organic $\mathrm{C}$ was reached in situ after between 5.5 and $15.5 \mathrm{~h}$, indicating that coral mucus can cause a rapid microbial response in the sediment and water column of reef environments, and that the added material was mineralised within less than a day.
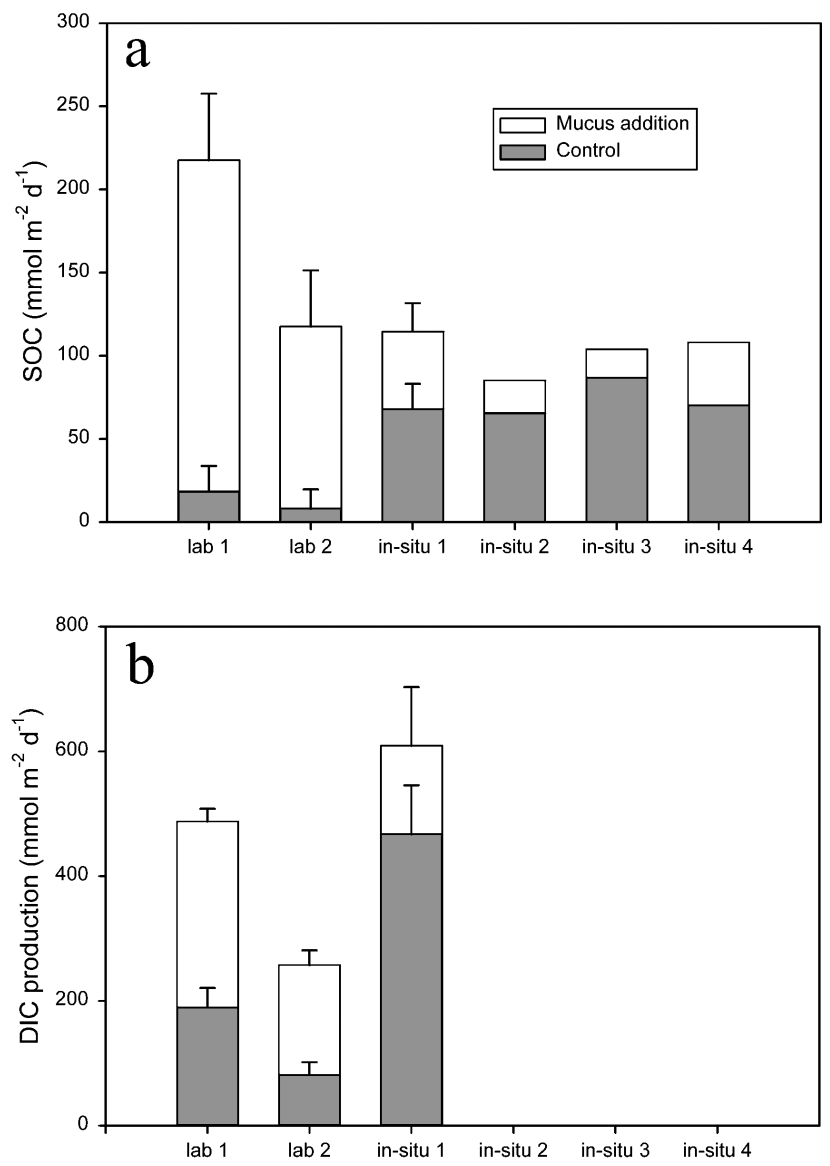

Fig. 8. Sedimentary $\mathrm{O}_{2}$ consumption (SOC); (a) and dissolved inorganic carbon (DIC) release (b) as calculated from all chamber incubation experiments. Open bars indicate mean chamber values with mucus (Acropora spp.) addition; gray bars show the control values. Error bars indicate the SDs of all experiments $(n=3)$ 


\section{DISCUSSION}

\section{Degradation of coral mucus in the water column}

The observed bacterial numbers on coral mucus were on average 100-fold higher than in the surrounding seawater (Table 3), and confirm the observation of Ducklow \& Mitchell (1979a) who reported an increased abundance of bacteria on coral mucus. These findings can explain the higher $\mathrm{O}_{2}$ consumption rates of mucus relative to seawater, and reveal that bacteria aerobically degrade coral mucus. Ferrier-Pages et al. (2000) showed that even small amounts of coral exudates can significantly stimulate microbial growth. Escherichia coli can survive in marine waters with coral mucus as the sole energy and nutrient source (Griffin 1999), and a significant number of mucus-colonising bacteria are able to grow on coral mucus as the sole source of carbon (Pascal \& Vacelet 1981). In addition, in incubation experiments with and without mucus from Acropora and Porites, Moriarty et al. (1985) found that the bacterial production in mucus-enriched seawater was significantly greater than in untreated seawater. These observations indicate that coral mucus is an attractive substrate for water column bacteria.

Nonetheless, Vacelet \& Thomassin (1991) characterised coral mucus as a poor, even inhibiting, medium for bacterial degraders in the water column, because they found (1) higher bacteria numbers in diluted than in pure mucus; (2) a lower percentage of dividing cells in coral mucus than in local seawater; and (3) higher bacterial production rates in cultures on peptone. The mucus webs they used in their long-term incubation experiments were not completely degraded, even after 21 d of incubation. Vacelet \& Thomassin (1991) surmised that water column bacteria utilise only certain components of the mucus, primarily the energy- and nutrient-rich components such as proteins, triglycerides and wax ester.

Notably, however, all authors agree that mucus is degraded partly in the water column. No inhibiting effect of coral mucus on bacterial growth and activity was observed, as reflected by our Winkler incubations showing an $\mathrm{O}_{2}$ consumption of coral mucus ranging from 130 to $445 \mu \mathrm{M} \mathrm{d}^{-1}$, which is much higher than the $\mathrm{O}_{2}$ consumption in the surrounding water. However, it is noted that other suspended aggregates can have much higher $\mathrm{O}_{2}$ consumption rates, as reported for diatom aggregates (2400 $\left.\mathrm{MM} \mathrm{d}^{-1}\right)$ (Ploug \& Grossart 2000).

\section{Where is coral mucus degraded?}

Higher $\mathrm{O}_{2}$ consumption rates in the benthic chambers with mucus, relative to the consumption rates measured in seawater with mucus, demonstrated that coral mucus is a degradable substrate for microbial communities in the sandy sediments of coral reef ecosystems. In the mucus used for in situ Expt 1, we measured an $\mathrm{O}_{2}$ consumption of $334 \mu \mathrm{M} \mathrm{d}^{-1}$. According to this rate, an addition of $280 \mathrm{ml}$ of this mucus to chambers with an average volume of 6.91 (as done during in situ Expt 1) would lead to a calculated increase in $\mathrm{O}_{2}$ consumption of approximately $14 \mu \mathrm{M}$ $\mathrm{d}^{-1}$. This consumption rate is ca. $5 \%$ of the oxygen consumption in the control chambers $(284 \pm 60 \mu \mathrm{M}$ $\mathrm{d}^{-1}$ ). However, we measured an average $\mathrm{O}_{2}$ consumption of $473 \pm 86 \mu \mathrm{M} \mathrm{d}^{-1}$ in the 3 mucus chambers. After subtraction of the consumption in the control chambers, this results in an increase in $\mathrm{O}_{2}$ consumption by $189 \mu \mathrm{M} \mathrm{d}^{-1}$ caused by the addition of coral mucus, a much higher increase than expected from the respiration measurements in the bottle incubations. According to this calculation, water column $\mathrm{O}_{2}$ consumption may only be responsible for less than $8 \%$ of the observed increase after the addition of coral mucus.

These findings lead to the conclusion that coral mucus added to the benthic chambers was primarily degraded in the carbonate sediment. High permeability of the carbonate sands permitted the transport of coral mucus into the permeable sands via interfacial water flows, where it was trapped by the rough surfaces of the carbonate grains. Due to this filtration process, the mucus became available to the sedimentary bacteria in the upper centimeters of the sands. Here, the number of bacteria per unit volume was 4 orders of magnitude higher than in the water column, causing the degradation rates of coral mucus in the sediment to exceed that in the water column by up to a factor of 12 . In addition, the biomass of bacteria in a coral reef was reported to be 100 to 200 times greater in the sediment compared to the entire water column (Wilkinson 1987). Moriarty et al. (1985) reported a 10-fold higher bacterial productivity in reef sediments compared to the water column.

We could not directly measure the trapping of coral mucus by the chamber sediments. Flow-through column experiments with the same sediments as those used in the chamber experiments showed that suspended mucus can easily be transported into the carbonate sands, with water flows percolating the sediment (C.W. \& M.H. unpubl. data). This may be an explanation as to why the results of this study initially contradicted the findings of Vacelet \& Thomassin (1991). It is likely that a highly diverse and dense sedimentary bacterial population, adapted to the decomposition of more refractory material, can decompose mucus more effectively than the bacterial community in the water column. 


\section{Degradation of coral mucus in the sediment}

In the laboratory chamber experiments, $\mathrm{O}_{2}$ consumption and DIC production after mucus addition were more pronounced than in the in situ experiments. This was caused by the higher flushing rates through the sieved sediments. Sieving removed the fine fraction from the coarse sand, resulting in more permeable sediments than the natural Shark Bay sediments (see Table 1). $\mathrm{O}_{2}$ penetration depth increases with increasing permeability due to faster transport of $\mathrm{O}_{2}$ into the sediment (Ziebis et al. 1996, Huettel \& Rusch 2000). More water and $\mathrm{O}_{2}$ could be carried into the sieved sediments per unit time, resulting in the higher $\mathrm{O}_{2}$ consumption rates we recorded in the coarse and medium sands. This flushing effect exceeded the effect of bacterial abundance that was 3 -fold higher in the medium sand. These explanations are supported by findings of Forster et al. (1996), Marinelli et al. (1998), Huettel \& Rusch (2000) and Dauwe et al. (2001), who also reported increased $\mathrm{O}_{2}$ consumption rates with increased sediment permeability. The lower $\mathrm{O}_{2}$ consumption rates in the laboratory control cores relative to the in situ controls may be caused by the removal of the fine fraction, containing the majority of the organic matter, during the sieving procedure.

Utilisation and degradation of coral mucus in the laboratory experiments with highly permeable sediment was most likely dominated by $\mathrm{O}_{2}$ respiration. This is supported by the calculated ratios of increased $\mathrm{O}_{2}$ consumption/DIC production after the addition of coral mucus. We found values of 0.64 (coarse sand) and 0.55 (medium sand) for the 2 laboratory experiments, but only 0.48 for the field experiment. These values show an imbalance between $\mathrm{O}_{2}$ consumption and DIC production in all experiments. The low value for the field experiment suggests a relatively large contribution of anaerobic processes, with $\mathrm{SO}_{4}{ }^{2-}$ or $\mathrm{NO}_{3}{ }^{-}$as electron acceptors (Jørgensen 1977, Thamdrup \& Canfield 1996) during utilisation and decomposition of coral mucus. Theoretically, the value between $\mathrm{O}_{2}$ consumption and DIC production should be 1 (Kristensen 2000), because of biological or chemical re-oxidation of reduced inorganic compounds. However, the short duration of our chamber experiments did not allow for complete oxidation of all reduced compounds.

Wilkinson (1987) reviewed that approximately $20 \%$ of the organic matter in coral reefs are degraded anaerobically by sedimentary bacteria. Our SRR measurements hint to $\mathrm{SO}_{4}{ }^{2-}$ reduction as an important process for the degradation of organic matter in permeable reef sediments. The SRR of $<1200 \mathrm{nmol} \mathrm{cm}^{-3} \mathrm{~d}^{-1}$ in a core taken from one of the mucus chambers at the end of in situ Expt 2 are twice as high as in the control cores. In other experiments with natural sediments at this site in January 2002, SRR never exceeded values of $660 \mathrm{nmol} \mathrm{cm} \mathrm{cm}^{-3} \mathrm{~d}^{-1}$ (U.W. unpubl. data).

Our finding that $\mathrm{O}_{2}$ can only penetrate 2 to $5 \mathrm{~mm}$ deep in these sediments supports the hypothesis that anaerobic processes are important for the degradation of organic matter in carbonate sands. The measured $\mathrm{O}_{2}$ penetration depths can be regarded as maximum values because of the 2-fold increase in stirring speeds in the chambers for $\mathrm{O}_{2}$ measurements with planar optodes compared to the stirring speed used for the in situ and laboratory incubations. We can therefore state that the oxic surface layer of reef sands may be even thinner than the $1 \mathrm{~cm}$ estimated by Skyring (1985).

Rasheed et al. (2003) suggested that high permeability, porous grains, and the mineralogy of carbonate sands are important factors making these sands sites for efficient organic matter degradation. Our results support this hypothesis and show that carbonate sands are able to act as biocatalytical filters that effectively degrade trapped coral mucus. Despite the complex carbohydrate matrix of coral mucus, this material was metabolised rapidly.

\section{Fate and importance of coral mucus}

Our observations in the Great Barrier Reef showed that coral mucus is not only produced in response to aerial exposure, but is continuously exuded by submerged hard, soft and fire coral, visible as strings that are released from the coral. These strings are only clearly visible if they are contaminated with material like detritus or fine carbonate grains.

The residence time of coral mucus in the water column depends on its consistency (dissolved or particulate) and the degree of contamination. The attachment of material can increase the density of mucus, leading to sinking and deposition. The degree of contamination itself is dependent on the amount of particles in the water column and, thus, also on weather conditions influencing the resuspension of benthic material into the water of shallow reef environments.

At Heron Island we observed that under the influence of tidal currents, mucus is washed from the coral heads and reacts with (re-)suspended material leading to a deposition of particle-loaded mucus aggregates onto the lagoon sediment surface within a few hours of release. Especially during extreme low tides, this process takes place twice a day. Nevertheless, we could not find any mucus accumulations in calm areas of the reef lagoon, which also indicates that mucus is rapidly degraded after reaching the sediment. This is also demonstrated by our chamber experiments, and shows that the permeable lagoon sediments of atolls, fringing and platform reefs function as biocatalytical filters. 
We conclude that coral mucus, a product from excess carbohydrate production by zooxanthellate photosynthesis, can act as a carrier for energy from the corals to the food chains of the reef (see also Wild et al. 2004). This mechanism is another example of the short-linked nutrient cycle between autotrophs and heterotrophs in coral reefs, which may contribute to the explanation for the high productivity of this ecosystem.

Acknowledgements. We thank B. B. Jørgensen for his support of this work and stimulating discussions. Thanks are also due to M. Alisch, S. Menger and S. Kremb for experimental assistance and help with the chemical analyses. We thank Ingo Klimant and Gregor Liebsch for fabrication of planar $\mathrm{O}_{2}$ optodes. Gerhard Holst and Björn Grunwald are acknowledged for support with the MOLLI system. We acknowledge O. Hoegh-Guldberg and R. Forbes of Heron Island Research Station (HIRS) for making this research at HIRS possible and logistical assistance. All sample collections and in situ experiments were done under permits QC00/102, G01/479 and G01/601 of the Great Barrier Reef Marine Park Authority. This research was funded by the Max Planck Society (MPG), Germany, and the Centre for Marine Studies (CMS) of the University of Queensland, Brisbane, Australia.

\section{LITERATURE CITED}

Benson A, Muscatine L (1974) Wax in coral mucus-energy transfer from corals to reef fishes. Limnol Oceanogr 19: 810-814

Coffroth MA (1984) Ingestion and incorporation of coral mucus aggregates by a Gorgonian soft coral. Mar Ecol Progr Ser 17:193-199

Coffroth MA (1990) Mucous sheet formation on poritid corals - an evaluation of coral mucus as a nutrient source on reefs. Mar Biol 105:39-49

Coles S, Strathman R (1973) Observations on coral mucus flocs and their potential trophic significance. Limnol Oceanogr 18:673-678

Crossland C, Barnes D, Borowitzka M (1980) Diurnal lipid and mucus production in the staghorn coral Acropora acuminata. Mar Biol 60:81-90

Daumas R, Galois R, Thomassin B (1982) Biochemical composition of soft and hard coral mucus on a New Caledonian lagoonal reef. Proc 4th Int Coral Reef Symp 2:59-68

Dauwe B, Middelburg J, Herman P (2001) The effect of oxygen on the degradability of organic matter in subtidal and intertidal sediments of the North Sea area. Mar Ecol Prog Ser 215:13-22

Davies PS (1984) The role of zooxanthellae in the nutritional energy requirements of Pocillopora eydouxi. Coral Reefs 2:181-186

Ducklow H, Mitchell R (1979a) Bacterial populations and adaptations in the mucus layers on living corals. Limnol Oceanogr 24:715-725

Ducklow HW, Mitchell R (1979b) Composition of mucus released by coral reef coelenterates. Limnol Oceanogr 24: 706-714

Ferrier-Pages C, Leclercq N, Jaubert J, Pelegri SP (2000) Enhancement of pico- and nanoplankton growth by coral exudates. Aquat Microb Ecol 21:203-209

Forster S, Huettel M, Ziebis W (1996) Impact of boundary layer flow velocity on oxygen utilisation in coastal sediments. Mar Ecol Prog Ser 143:173-185
Glud RN, Forster S, Huettel M (1996a) Influence of radial pressure gradients on solute exchange in stirred benthic chambers. Mar Ecol Prog Ser 141:303-311

Glud RN, Ramsing NB, Gundersen JK, Klimant I (1996b) Planar optrodes - a new tool for fine scale measurements of two-dimensional $\mathrm{O}_{2}$ distribution in benthic communities. Mar Ecol Prog Ser 140:217-226

Glud RN, Santegoeds CM, DeBeer D, Kohls O, Ramsing NB (1998) Oxygen dynamics at the base of a biofilm studied with planar optodes. Aquat Microb Ecol 14:223-233

Goldberg W (2002) Feeding behavior, epidermal structure and mucus cytochemistry of the scleractinian Mycetophyllia reesi, a coral without tentacles. Tissue Cell 34:232

Gottfried MRM (1983) Ingestion and incorporation of coralmucus detritus by reef zooplankton. Mar Biol 72:211-218

Grange K (1991) Mutualism between the Antipatharian Antipathes fiordensis and the Ophiuroid Astrobrachion constrictum in New Zealand fjords. Hydrobiologia 216: 297-303

Griffin DW (1999) Microbiological studies of Florida water quality. PhD thesis, University of South Florida, St. Petersburg, FL

Hall POJ, Aller RC (1992) Rapid, small-volume, flow injection analysis for $\mathrm{SCO}_{2}$ and $\mathrm{NH}_{4}{ }^{+}$in marine and freshwaters. Limnol Oceanogr 37:1113-1119

Herndl GJ, Velimirov B (1986) Microheterotrophic utilization of mucus released by the Mediterranean coral Cladocora cespitosa. Mar Biol 90:363-369

Hickel W (1974) Seston composition of the bottom waters of Great Lameshur Bay, St. John, US Virgin Islands. Mar Biol 24:125-130

Hobbie JE, Daley RJ, Jasper S (1977) Use of nucleopore filters for counting bacteria by fluorescence microscopy. Appl Environ Microbiol 33:1225-1228

Hubbard JAE, Pocock YP (1972) Sediment-rejection by recent scleractinian corals: a key to palaeo-environmental reconstruction. Geol Rundsch 61:598-626

Huettel M, Gust G (1992) Solute release mechanisms from confined sediment cores in stirred benthic chambers and flume flows. Mar Ecol Prog Ser 82:187-197

Huettel M, Rusch A (2000) Transport and degradation of phytoplankton in permeable sediment. Limnol Oceanogr 45:534-549

Ikeda Y, Miyachi S (1995) Carbon dioxide fixation by photosynthesis and calcification for a solitary coral, Fungia sp. Bull Inst Oceanogr 14:61-67

Johannes R (1967) Ecology of organic aggregates in the vicinity of a coral reef. Limnol Oceanogr 12:189-195

Jørgensen BB (1977) The sulfur cycle of a coastal marine sediment (Limfjorden, Denmark). Limnol Oceanogr 22:814-832

Kautsky H (1939) Quenching of luminescence by oxygen. Trans Faraday Soc 35:216-219

Kinsey DW (1983) Standards of performance in coral reef primary production and carbon turnover. In: Barnes DJ (ed) Perspectives on coral reefs. Brian Clouston Publishing, Canberra

Klimant I, Meyer V, Kühl M (1995) Fiber-optic oxygen microsensors, a new tool in aquatic biology. Limnol Oceanogr 40:1159-1165

Klute A, Dirksen C (1986) Hydraulic conductivity and diffusivity: laboratory methods. In: Klute A (ed) Methods of soil analysis, Part 1-physical and mineralogical methods, 2nd edn. American Society of Agronomy, Madison, WI

Kristensen E (2000) Organic matter diagenesis at the oxic/ anoxic interface in coastal marine sediments, with emphasis on the role of burrowing animals. Hydrobiologia 426: $1-24$ 
Krupp DA (1984) Mucus production by corals exposed during an extreme low tide. Pac Sci 38:1-11

Krupp DA (1985) An immunochemical study of the mucus from the solitary coral Fungia scutaria (Scleractinia, Fungiidae). Bull Mar Sci 36:163-176

Lewis JB (1977) Processes of organic production on coral reefs. Biol Rev Camb Phil Soc 52:305-347

Lewis JB (1978) Feeding mechanisms in black corals (Antipatharia). J Zool 186:393-396

Lewis JB, Price WS (1976) Patterns of ciliary currents in Atlantic reef corals and their functional significance. J Zool 178:77-89

Marinelli RL, Jahnke RA, Craven DB, Nelson JR, Eckman JE (1998) Sediment nutrient dynamics on the South Atlantic Bight continental shelf. Limnol Oceanogr 43:1305-1320

Marsden J, Meeuwig J (1990) Preferences of planktotrophic larvae of the tropical serpulid Spirobranchus giganteus (Pallas) for exudates of corals from a Barbados reef. J Exp Mar Biol Ecol 137:97-104

Marshall M (1968) Observations on organic aggregates in the vicinity of coral reefs. Mar Biol 2:50-55

Moriarty DJW, Pollard PC, Alongi DM, Wilkinson CR, Gray JS (1985) Bacterial productivity and trophic relationships with consumers on a coral reef (MECOR 1). Proc 5th Int Coral Reef Cong, Tahiti, Vol 3, p 457-462

Odum HT, Odum EP (1955) Trophic structure and productivity of a windward coral reef community on Eniwetok atoll. Ecol Monogr 25:291-320

Pascal H, Vacelet E (1981) Bacterial utilization of mucus on the coral reef of Aqaba (Red Sea). Proc 4th Int Coral Reef Symp 1:669-677

Patton W (1994) Distribution and ecology of animals associated with branching corals (Acropora spec.) from the Great Barrier Reef, Australia. Bull Mar Sci 55:193-211

Ploug H, Grossart HP (2000) Bacterial growth and grazing on diatom aggregates: respiratory carbon turnover as a function of aggregate size and sinking velocity. Limnol Oceanogr 45:1467-1475

Rasheed M, Badran M, Huettel M (2003) Particulate matter filtration and seasonal nutrient dynamics in permeable carbonate and silicate sands of the Gulf of Aqaba, Red Sea. Coral Reefs 22:167-177

Editorial responsibility: Otto Kinne (Editor), Oldendorf/Luhe, Germany
Richards GN, Meikle PJ, Yellowlees D (1983) Preliminary investigations into the chemical nature of mucus from the staghorn coral (Acropora formosa). Proc Inaug Great Barrier Reef Conf, Vol 1, p 353-359

Richman S, Loya Y, Slobodkin L (1975) Rate of mucus production by corals and its assimilation by the coral reef copepod Acartia negligens. Limnol Oceanogr 20:918-923

Rinkevich B, Wolodarsky Z, Loya Y (1991) Coral crab association-a compact domain of a multilevel trophic system. Hydrobiologica 216:279-284

Rublee P, Lasker H, Gottfried M, Roman M (1980) Production and bacterial colonization of mucus from the soft coral Briarium asbestinum. Bull Mar Sci 30:888-893

Schlichter D, Svoboda A, Kremer BP (1983) Functional autotrophy of Heteroxenia fuscescens (Anthozoa: Alcyonaria): carbon assimilation and translocation of photosynthates from symbionts to host. Mar Biol 78:29-38

Schuhmacher H (1977) Ability of fungiid corals to overcome sedimentation. Proc 3rd Int Symp Coral Reefs Manila, Vol 1, p 503-509

Shafir A, Loya A (1983) Consumption and assimilation of coral mucus by the burrowing mussel Lithophaga lessepsiana. Proc Int Conf Mar Sci Red Sea 9:135-140

Skyring GW (1985) Anaerobic microbial processes in coral reef sediments. Proc 5th Int Coral Reef Cong 3:421-425

Stachowicz JJ, Hay ME (1999) Mutualism and coral persistence: the role of herbivore resistance to algal chemical defense. Ecology 80:2085-2101

Thamdrup B, Canfield DE (1996) Pathways of carbon oxidation in continental margin sediments off central Chile. Limnol Oceanogr 41:1629-1650

Vacelet E, Thomassin B (1991) Microbial utilization of coral mucus in long term in situ incubation over a coral reef. Hydrobiologia 211:19-32

Wild C, Huettel M, Klueter A, Kremb SG, Raheed M, Jørgensen BB (2004) Coral mucus functions as energy carrier and particle trap in the reef ecosystem. Nature (in press)

Wilkinson CR (1987) Microbial ecology on a coral reef. Search 18:31-33

Ziebis W, Huettel M, Forster S (1996) Impact of biogenic sediment topography on oxygen fluxes in permeable seabeds. Mar Ecol Prog Ser 140:227-237

Submitted: July 3, 2003; Accepted: September 27, 2003

Proofs received from author(s): January 9, 2004 